\title{
Tropical Freedom: Climate, Settler Colonialism, and Black Exclusion in the Age of Emancipation
}

\author{
Review Number: 2269
}

Publish date: Thursday, 26 July, 2018

Author: Ikuko Asaka

ISBN: 978-0822369103

Date of Publication: 2017

Price: $£ 19.99$

Pages: 304pp.

Publisher: Duke University Press

Publisher url: https://www.dukeupress.edu/tropical-freedom/index.html

Place of Publication: Durham

Reviewer: Tiffany King

Ikuko Asaka opens this ambitious book by referencing the climatic and geographic rebuttal of black journalist and abolitionist Mary Ann Shadd. In an 1852 pamphlet, advocating black emigration to Canada, Shadd argued that due to the transatlantic slave trade, African descendants were highly adaptable people who could live and labor in a wide range of climates that encompassed the frigid north seas of British North America to the sweltering West Indies. Throughout Asaka's innovative historiography that traces how the 'idea of tropical freedom played a constitutive part in Anglo American expansionist processes', she mines a broad spectrum of archival sources to carefully reconstruct how a transnational campaign to relocate formerly enslaved black people in Upper Canada (the British Empire), the US colonies - the early republic and what would become the United States emerged during the late 18th century and gained traction in the mid 19th century. This transnational effort to move black 'free labor' from North America to West Africa, the Caribbean and Central America produced and was simultaneously driven by the emergence of a shared vocabulary of Black tropicality (p. 202). While patiently and carefully tracing this discourse of 'climatic determinism', Asaka also agilely tracks black counter discourses to 'climatic determinism' and black displacement. Asaka traces the contours of a dual and dueling spatial dialogue that spans almost a century.

As an attentive guide and writer, Asaka weaves in Mary Shadd's voice and presence throughout the book to create a through line of black resistance to spatial domination. Asaka mines the correspondence and records of the American Colonization Society; British and American Abolitionist papers; documents drafted by officers of British Colonial Land and Emigration Commissions in Canada, the West Indies, Liberia and Sierra Leone; Nova Scotian records of black settlement; and reports from the Canadian Church and School Society's 'Mission to Colored Population in Canada'. Some of Asaka's most interesting archival work collects and interprets black abolitionists' and fugitives' pamphlets, newspapers and accounts in order to construct the emergence, shifts in and deployment of a black geographic narrative of 'climatic adaptability' (p. 183) and black belonging in all of the Americas. Asaka's notable attention to the abolitionist newspaper, the Emancipator, sheds light on the vast range of activities that can be considered abolition work.

For example, Asaka gives accounts of the myriad ways that Mary Ann Shadd and her contemporaries Peter Gallego and Eduard de St. Remy advocated for, as Asaka calls them, 'former-slave refugees' and 'self- 
emancipated people' (p. xii) beyond assisting in escapes and providing safe harbor. For example, Gallego and St. Remy advocated for 'fugitive refugees' (p. 68) who crossed the border into Upper Canada in the 1830s by lobbying for employment, schooling, and freedom from racial harassment once formerly enslaved people settled in Canada. Asaka's collection of archival records reveals that abolition was a form of activism that extended beyond advocating for the abolition of slavery and assisting enslaved people's flight. Abolition also includes the fight for black survival and the right to exist and make a place for oneself upon arrival in Canada or a 'free' territory. Recounting Shadd's, Gallego's and St. Remy's activism also helps to map a complicated terrain of black geographic discourse and debate about black emigration schemes and the highly racialized discourse of black tropicality.

Tracking black abolitionists' debates about emigration and racialized climatic discourse back to the 18th and early 19th centuries allows Asaka to intervene upon normative periodizations and geographies of American and British black colonization schemes. Asaka's primary intervention as a historian disrupts conventional historiographies that reconstruct the 'freedom-slavery' dichotomy that produces Canada as a space of black freedom and the US as a slave regime that did not have to grapple with the presence of free black labor. Tropical Freedom's historical inquiry reveals how 'slavery's legacy helped make freedom a racially defined geographic concept in the United States and British North America' that was fundamentally entangled with settler colonialism (p. 203). Filling 'chronological gaps' in histories of 'racialized climatic geographies of labor' (p. 7), Asaka devotes attention to the decades between the American Revolution and the Civil War. Asaka's periodization, which starts almost 100 years prior to the Civil War, reframes black emigration schemes as an integral project of the British Empire before the abolition of slavery in the British colonies. Asaka's re-periodization and re-spatialization of the problem that black 'free labor' posed for Anglo settler colonial expansion extends the geographic frame beyond a hemispheric approach (US, Canada, Central America and the Caribbean) stretching across the Atlantic to Britain, Sierra Leone, Liberia. This is in contrast to most historiographies of black emigration which remain US-centric and tethered to the Lincoln presidency and its dramatic backdrop, the Civil War.

Tropical Freedom attends to the important role that the Revolutionary War and the War of 1812 played in producing populations of emancipated black people who participated as soldiers. Both the early republic and the British empire had to contend with the Revolutionary War's black loyalists and the War of 1812's veterans as free black populations who represented both a pool of 'free labor' as well as potential agitators for the abolition of slavery in the United States and throughout the British empire. In Tropical Freedom's comparative and transnational history, Asaka remaps the geographic field of settler colonialism and considers the ways that US and British spatial imaginaries constructed North America as a white temperate space while attempting to expand Anglo settler colonial domination into Latin America and across the Atlantic to Liberia and Sierra Leone. Methodologically rooted in historical methods, Asaka's capacious transnational history of the reach of settler colonial imaginaries through a discourse of climate manages to contribute to interdisciplinary discussions in fields as far reaching as critical geography, Black Canadian studies, US slavery, setter colonial studies and gender and sexuality studies. Working at the intersection of settler colonialism and black dislocation (p. 9), Asaka attempts to grapple with the analytic, conceptual and methodological challenge of keeping the Indigenous-Settler-Black triad in play. The difficultly of this task is apparent as Asaka moves from chapter to chapter.

While all of the chapters do a formidable job of bringing British and US slavery, Black fugitives, Black mobility, Black free populations, abolitionist campaigns and enslavement and enduring racial discourses of climate determinism into conversation with settler colonial discourse and analytics, Asaka has a hard time keeping Indigenous people in the frame. Other than acknowledging of the persistence of Indigenous erasure and land theft, and broaching the issue of Black free and fugitive people's emerging conflict with Indigenous people over the land, Asaka rarely discusses indigeneity in the book. Chapter one traces the emergence of the tropical and temperate region dichotomy in the archive that delineates the black tropical, largely tenantoccupied space of hot grueling agricultural labor in West Africa and the West Indies and the white temperate settler space of North America and Britain. Chapter two attends to the livelihood of former 'slave fugitives' who escaped to Canada. The chapter also attempts to keep track of the sophisticated ways in which free 
Blacks in the US made distinctions between their lobbies for freedom to the US government and the ways that Black fugitives living in Canada aligned themselves with the British Crown during the 1837 Rebellion in Upper Canada. Chapter three establishes the 1840s as the decade in which the notion of black tropicality became a dominant and widespread transnational discourse that was deployed by both proponents and opponents of British and US black emigration and removal. Chapter four focuses on the ways that Africans living in America and Canada used discourses and representations of mobility to challenge notions of black tropicality and climatic determinism. In chapter four, Asaka also discusses the ways that 'African North Americans', especially African Canadians, used the trope of mobility as a way to reconstruct black gender and family formations as respectable, productive and therefore assimilable into settler nations. Chapter five extends upon the ways that African North Americans developed an alternative idea of race and environment (p. 19) and chapter six concludes the book with US emancipation, which is where most historical treatments of tropicality, black removal and colonization in West Africa, West Indies and Central America begin. While Asaka achieves the formidable task of bringing black enslavement, fugitivity and settlement into the frame to disrupt the conventional Settler-Indigenous binary maintained by settler colonial studies, indigeneity is largely left untouched.

Far from being an individual failure on the part of Asaka as a scholar, the challenge of keeping all parts of the Indigenous-Settler-Black triad in play is a larger conceptual and methodological problem that plagues various disciplinary and interdisciplinary attempts to figure black people and slavery into settler colonial relations in North America. Another debate and site of tension that arises in the fields of settler colonial studies, Indigenous Studies and Black Studies that Asaka alludes to in the book is the question of how to name enslaved and formerly enslaved African people living - and settling - in North America. Debate persists about whether descendants of African slaves should be included into or absorbed by the category settler. While Asaka does not explicitly stake a claim or weigh in on the debate, the way that she creates and imposes national assignations upon black people residing (and settling) in the US and Canada works to interpellate them as settlers and quasi-citizens of settler-nation states. In the 'Note on terms' section before the introduction, Asaka creates delineations for the reader. For example, Asaka notes that she refers to people of African descent living in the United States as 'African Americans or black Americans' (p. xi). Asaka refers to people of African descent born in the US who escaped or migrated to Canada and identified themselves as British colonial subjects in Canada as 'African Canadians or black Canadians'. She also uses the term 'African North Americans' to refer to African and Canadian Americans who are subjected to the 'patterns of control operating across the Canada-U.S. border' (p. xi).

Making distinctions between the experiences of people of African descent living in North America is essential both for the reader and the task of creating a kind of conceptual clarity that avoids conflating and flattening the lived experiences of black people in the US and Canada. Though Asaka creates definitions and terms to help the reader avoid confusion, I found the delineations slippery and particularly hard to follow in chapter two. During Asaka's discussion of the Rebellion of 1837 in which members of the Ontario provincial parliament in Toronto 'initiated a rebellion to free Canada from British rule' (p. 62), some of Asaka's national designations become muddled and confusing. Asaka provides an important account of the anti-black animus and resentment that arose amongst white Canadians and white Americans (citizens) in response to some black residents of Canada's decision to support the British during the 1837 Rebellion. Both Black people residing in Canada and in the US, specifically in the border town of Buffalo, New York, experienced white aggression from Canadians and Americans who read black people - African North Americans - living in the border region as outsiders and supporters of the British Crown. In response to the white aggression, Asaka explains that African Americans in Buffalo attempted 'to dissociate themselves from the Canadian soldiers' (p. 65). Asaka's discussion of the way that black people on the border in the US marked differences between 'black American' and 'black Canadian' identity in chapter two is the first place where Asaka's decision to assign Black people residing in Canada and in the US national designations (and implicitly mark them as citizens) became confusing for me.

For instance, when Asaka provides an account of the ways that 'Black citizens on the border areas understood that the paranoia stemmed from whites' conflation of black Americans with black Canadian 
soldiers, with both considered non-American foreign elements' (pp. 64-5), and had to respond to white hostility, I became acutely aware of Asaka's discursive slippages - or conflations - that too easily mapped Canadian and US citizenship onto black people residing in each country. Certainly, the Black people living in Canada in 1837 - particularly those fighting for the British - were not considered Canadian citizens and the black people living in the United States could also not be considered citizens. In fact, the black soldiers fighting for the Crown considered themselves British subjects and were fighting against white Canadian soldiers and citizens. Chapter two is where I found Asaka's assignments of Canadianness to Black people living in Canada and Americanness to Black people living in the United States overstated. These designations too easily confer citizenship onto the Black people living in Canada and the United States and subsequently smuggle in the idea of a Black Canadian or Black US patriot.

Additionally, I am skeptical of Asaka's discussion of Black residents of New York's strategic and time bound critiques of the British incursion into Canada (and Black support in Canada of the British) and monarchial systems as acts of American patriotism. In my opinion, Asaka is too quick to mark the strategic distinctions free Black people in New York made between refugees in Canada who were granted freedom 'by a foreign power' (p. 67) and themselves whose freedom came under US law (to which Asaka claims they were indebted). In fact, immediately after Asaka carves out these distinctions between free Black New Yorkers and self-emancipated Canadians, Asaka admits that the false dualism erodes when the Fugitive Slave Act of 1850 is passed. Though I appreciate Asaka's impulse to carefully attend to the specific contexts and shifting dynamics that African North Americans experienced on their respective sides of the USCanadian border, I find Asaka too easily transforms free Black residents of New York's strategic discursive and rhetorical maneuvers to protect themselves from white American violence into gestures of patriotism and allegiance to the US nation. During these moments of black 'patriotism' in Tropical Freedom, my thoughts travelled immediately to Frederick Douglas's 1852 speech 'What to a Slave is the Fourth of July'.

However, Asaka's archival work and careful attention to the discursive, rhetorical and material ways that black people attempted to settle in Canada and become normative or less abject subjects (in order to survive and not return to slavery) is where Asaka is at her best. In chapters four and five, Asaka is able to tell a textured yet coherent story about how black subject formation in settler colonial Canada was ordered, produced and constrained along the lines of material and discursive regimes of white settler coloniality. Asaka does a wonderful job of describing the paradoxical ways that Blacks were excluded from Homestead Acts that granted tracts of land to white settlers in the North American West while also being offered opportunities for land ownership in Latin America, the Caribbean and on a very tenuous basis in Ontario and the US South. While Black people were largely excluded from landownership and settlement in North America, they were granted opportunities to own land in places like Liberia, Sierra Leone, Chiriqui and the West Indies. Both the US and Britain intended to use Christianized, English speaking Black families to gain a foothold in Latin America, the Caribbean and West Africa for the consolidation of white Anglo settler colonial power. In chapters four and five, Asaka is able to align (and at times implicate) Black desires for freedom from slavery and racist violence with capitulations albeit vexed to the settler colonial project without overstating Black subject formation as a nationalistic identitarian claim. The conceptual and methodological challenges that Asaka contends with in Tropical Freedom will prove instructive for scholars grappling with the question of how to introduce slavery, Black fugitivity and freedom into settler colonial interpretive frames and analytics. While Asaka's Tropical Freedom is undoubtedly a contribution to historiographies of Black colonization, it is also represents a significant contribution to the fields of settler colonial studies, Black Studies, gender and sexuality studies, critical geographies and race and space scholarship. Tropical Freedom is an important book to read and teach.

Source URL:https://reviews.history.ac.uk/review/2269

\section{Links}

[1] https://reviews.history.ac.uk/item/295054 